Bulletin de la Société entomologique de France, 119 (2), 2014 : 197-198.

\title{
Alain Ratnadass \& Sean Moore. - Citrus spp. (Rutaceae), cited for the first time as a host plant for Eurystylus capensis (Hemiptera, Miridae)
}

Mirid plant bugs of the genus Eurystylus Stål, 1871, have been reported as major pests of Sorghum [Sorghum bicolor (L.) Moench] in West and Central Africa (WCA), and to a lesser extent of Castor bean (Ricinus communis L.) in Southern Africa (STONEDAHL, 1995). It is now recognized that the main species causing damage to Sorghum in the former region is Eurystylus oldi Poppius, 1912, as all other species reported have been recognized since either as synonyms or as misidentifications (RATNADASS et al., 1994; STONEDAHL, 1995). However, the occurrence of another species causing minor damage to Sorghum in West Africa and South Asia, namely E. bellevoyei (Reuter, 1879), is also recognized. While distribution of $E$. old $i$ is virtually limited to SubSaharan Africa and its host range is rather narrow, distribution of $E$. bellevoyei encompasses the whole African continent, the Indian Ocean islands, Southern Europe, the Arabic peninsula and South Asia (Matoce \& Streito, 2013). It was reported on a broad range of hosts, particularly Sorghum in South Africa (KRUGER et al., 2008) and Gynandropsis gynandra (L.) Briq. in Niger (RATNADASS et al., 2012).

Eurystylus oldi was not considered a pest of Sorghum in South Africa, but of Castor bean and Sunn hemp (Crotalaria juncea L.) in Mozambique (Maldès \& RATNADASS, 1998). Eurystylus rubroscutellatus Odhiambo, 1958, was also reported from Southern Africa, but with an unknown host association. In South Africa, besides E. bellevoyei (see above), E. capensis (Distant, 1904) was recorded in the Eastern Cape (King William's Town) and in Pretoria, (StONEDAHL, 1995).

However, it is only during the last few years, that this latter species has been observed on citrus (all commercial types excluding lemons), and to be causing notable damage to citrus blossoms in the Eastern Cape Province. It was observed that the adults and late instar nymphs fed on the closed citrus blossoms, causing yellow/brown lesions, leading to the blossoms prematurely dropping off. There have been claims of yield reduction. Both adults and juveniles were collected from Avoca Farm
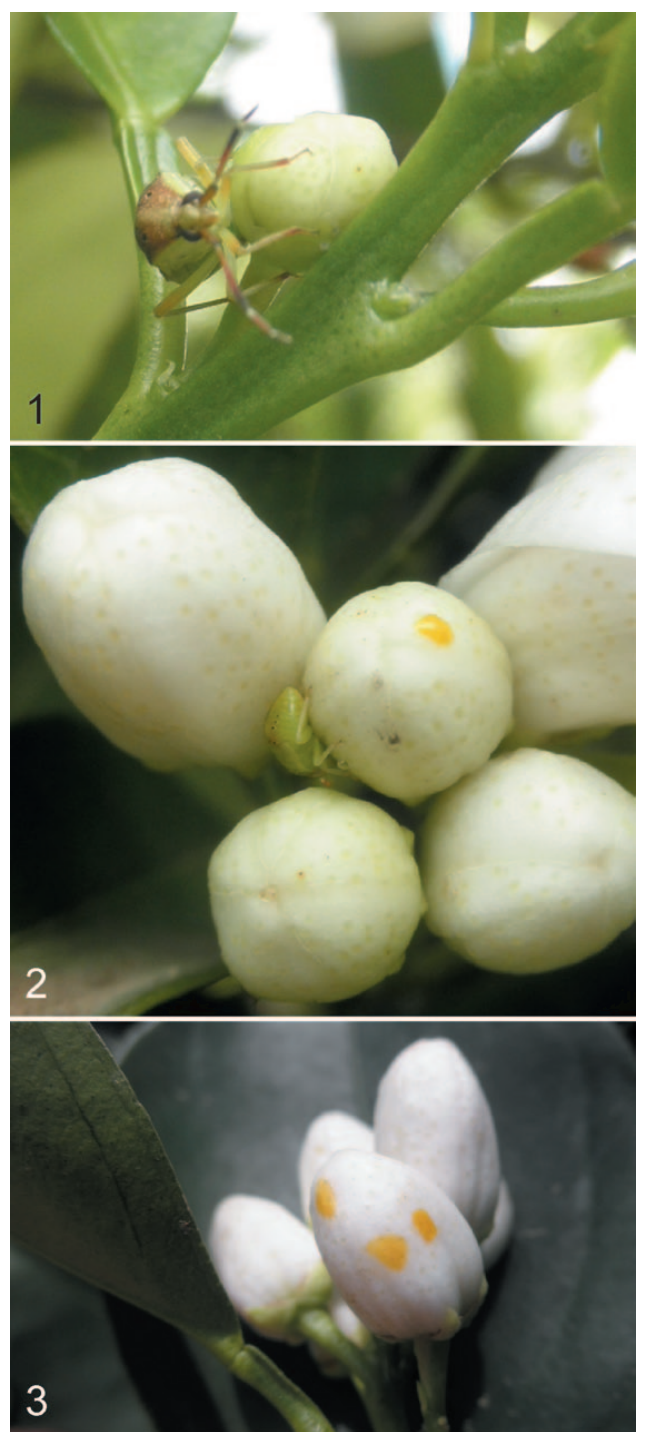

Fig. 1-3. - 1, An adult of Eurystylus capensis (Distant) on a citrus blossom. $-2, \mathrm{~A} 4^{\text {th }}$ instar nymph of $E$. capensis on a closed citrus blossom with droplet of yellow exudate where it has fed. -3 , Extensive damage on closed citrus blossoms, later translating into yellow/brown lesions, $\left(33^{\circ} 28^{\prime} 42^{\prime \prime} \mathrm{S}-25^{\circ} 35^{\prime} 43^{\prime \prime} \mathrm{E}\right)$ in the Sundays leading to the blossoms prematurely dropping off the tree. 
River Valley of Eastern Cape Province in South Africa on Navel orange trees on 7 October 2013. The presence of nymphs $\left(3^{\text {rd }}, 4^{\text {th }}\right.$ and $5^{\text {th }}$ instar $)$ on the blossoms indicates that these bugs are breeding in the trees. In fig. 2-3, one can see where they have inserted their proboscises into the closed blossom, which then leads to the blossom dropping off the tree.

This is the first time that a species of the genus Eurystylus has been reported as a fruit tree pest, and being able to breed in a fruit tree. Adults of E. oldi (but not nymphs) have previously been found on mango blossoms in West Africa, but they were not reported to cause any damage (AJAYI \& AJiBOYE, 1997). Previously, only Croton megalobotrys Müll. Arg. and Vitex agnus-castus L. shrubs have been reported as hosts of E. capensis (in Pretoria, South Africa), sheltering both adults and nymphs of the species (STONEDAHL, 1995). Further observations are needed on citrus to quantify the damage caused, to check whether other species of Eurystylus are involved, and to identify other potential alternate hosts of E. capensis in the region [e.g. Croton megalobotrys, Vitex agnus-castus, or even Ricinus communis (RATNADASS et al., 1997)], and to inspect the same for possible presence of bugs of other Eurystylus species, e.g. E. oldi and E. bellevoyei.

\section{REFERENCES}

AJAYI O. \& AJiBOYE T. O., 1997. - Non crop host plants of the sorghum head bug, Eurystylus oldi in west Africa. International Sorghum and Millets Newsletter, 38: 81-82.

Kruger M., Van Den Berg, J. \& Du Plessis H. 2008. - Diversity and seasonal abundance of sorghum panicle-feeding Hemiptera in South Africa. Crop Protection, 27 (3-5): 444-451.

MALDÈs J. M. \& RATnAdASS A., 1998. - Crotalaria juncea (Fabaceae) citée pour la première fois comme hôte alternatif d'Eurystylus oldi important ravageur africain du Sorgho et du Ricin (Hem., Miridae). Bulletin de la Société entomologique de France, 103 (3): 272.

MatocQ A. \& Streito J.-C. 2013. - Données sur trois espèces d'Hétéroptères nouvelles pour la France (Hemiptera Miridae et Anthocoridae). L'Entomologiste, 69 (1): 3-7.

Ratnadass A., Cissé B., Diarra D. \& Sangaré M. L., 1997. - Indigenous host plants of sorghum headbugs (Heteroptera: Miridae) in Mali. African Entomology, 5 (1): 158-160.

Ratnadass A., Cissé B. \& Mallé K., 1994. - Note on the biology and immature stages of West African sorghum head bugs Eurystylus immaculatus and Creontiades pallidus (Heteroptera: Miridae). Bulletin of Entomological Research, 84: 383-388.

Ratnadass A., Rabo Y., Salha H., MatocQ A. \& Doumma A., 2012. - Gynandropsis gynandra (Capparidaceae) citée pour la première fois comme hôte d'Eurystylus spp. (Hemiptera, Miridae). Bulletin de la Société entomologique de France, 117 (1): 115-118.

Stonedahl G. M., 1995. - Taxonomy of African Eurystylus (Heteroptera: Miridae), with a review of their status as pests of sorghum. Bulletin of Entomological Research, 85: 135-136.

(A. R.: CIRAD, UR HortSys, TA B-103/PS4, F-34398 Montpellier Cedex 5 <alain.ratnadass@cirad.fr> S. M. : Citrus Research International, PO Box 20285, Humewood 6013, South Africa, and Department of Zoology and Entomology, Rhodes University, Grahamstown, South Africa <SeanMoore@cri.co.za>) 